\title{
ÖNKORMÁNYZATI BIZALOM ÉS A KOOPERATÍV KÖZSZOLGÁLTATÁSOK ELMÉLETE
}

\author{
KATONA MÁRTON* - ROSTA MIKLÓS \\ Budapesti Corvinus Egyetem, Összehasonlító és Intézményi Gazdaságtan Tanszék
}

\begin{abstract}
A közpolitika és a bizalom kapcsolatának vizsgálata talán napjaink egyik legaktuálisabb kérdése, mind az akadémia, mind a politika területén. Tanulmányunkban ${ }^{1}$ arra vállalkozunk, hogy a hazai és nemzetközi szakirodalom alapján áttekintjük az intézményi bizalom, különösképp a politikai intézményekbe vetett bizalom főbb magyarázó tényezőit. Ezt követően bemutatjuk a kooperatív közszolgáltatások elmélet föbb elemeit és ez alapján megvizsgáljuk, hogy az elmélet mennyiben járulhat hozzá az önkormányzatokba vetett bizalom növekedéséhez. Úgy találtuk, hogy az elmélet megvalósítása esetében az állampolgári részvétel erősítése és a közszolgáltatások minőségénének javítása, ami elsődlegesen javíthatja az önkormányzatokba vetett bizalmat.
\end{abstract}

Kulcsszavak: kooperatív közszolgáltatások, politikai bizalom, önkormányzati bizalom

The relationship between public policy and trust is one of the most current issues both in academia and politics. In our study based on national and international literature we scrutinize the main explanatory factors of institutional trust, especially the trust in political institutions. We present the main elements of the coproduction theory and we examine how the theory can contribute to increasing confidence in local governments. It has been found that through strengthening citizen participation and improving the quality of public services the confidence in local governments could increase.

Keywords: coproduction, political trust, trust in local governments

* Levelező szerző: Katona Márton, egyetemi tanársegéd, Budapesti Corvinus Egyetem, Összehasonlító és Intézményi Gazdaságtan Tanszék,1093 Budapest, Fővám tér 8. E-mail: marton.katona@uni-corvinus.hu

1 A kiadvány/publikáció a Széchenyi 2020 program által az EFOP-3.6.1-16-2016-00013 „Intelligens szakosodást szolgáló intézményi fejlesztések a Budapesti Corvinus Egyetem székesfehérvári Campusán" címü uniós projekt keretében készült. 


\section{Bevezetés}

A legtöbb fejlett demokráciában - eltérő mértékben - a kormányzatba és a politikai intézményekbe vetett bizalom csökkenése volt megfigyehető az elmúlt évtizedekben (K. Blind 2007).

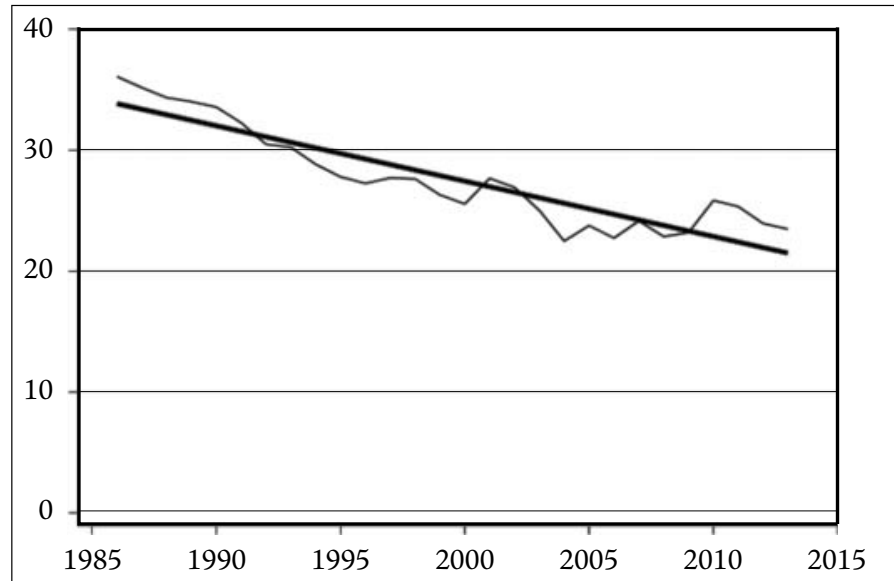

1. ábra: A kormányba vetett bizalom Nagy-Britanniában (Forrás: Jennings et al. 2015: 16)

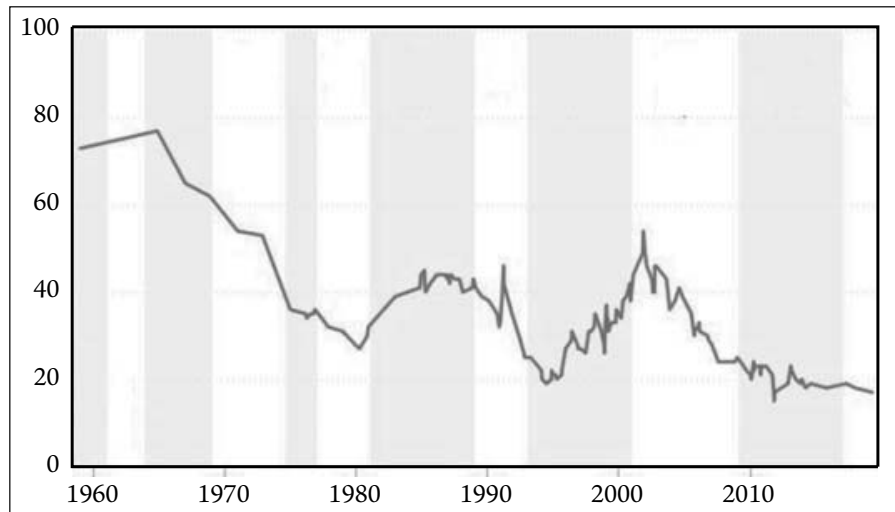

2. ábra: A kormányba vetett bizalom az Egyesült Államokban (Forrás: Pew Research Center 2019)

$\mathrm{A} z$ 1. és 2. ábrán szemléltetésképpen Nagy-Britanniában és az Egyesült Államokban készült felmérések eredményeit mutatjuk. Nem véletlen, hogy az intézményi bizalom a politikatudománnyal, a szociológiával (Kontler-Somos 2017) és a közgazdaságtudománnyal foglalkozó tudósok körében is egyre népszerübb témává vált. A jelenség pontos leírása, valamint az okok feltárása kifinomultabb módszereket és a valósághoz jobban illeszkedő elméleteket követelt a kutatóktól. Ennek során a figyelem középpontjába ke- 
rült, hogy mely tényezők azok, amelyek befolyásolják az állampolgárok politikai rendszerbe vetett bizalmát (Lidström 2008). ${ }^{2}$

Habár a demokrácia és bizalom pozitív kapcsolatával, illetve a bizalom társadalomban betöltött szerepével már Thomas Hobbes és John Locke is foglalkozott (Newton 2006; Hardin 1999), több mint 300 évvel később sem állíthatjuk, hogy minden kérdést megválaszoltunk ezen a területen. Érdekes látni, hogy miközben az Európai Unió kitüntetett figyelmet szentel az intézményi bizalom kérdésének (Eurobarometer 2017), a fejlett európai országok is lemaradtak a bizalom kutatása terén (főként annak közpolitikai vonatkozásaival) az Egyesült Államokkal szemben (Boda 2015), van tehát teendő és feladat a terület kutatói előtt.

Tanulmányunkban az állampolgárok poltikai intézményekbe, azon belül is az önkormányzatokba vetett bizalmának magyarázó tényezőinek feltárására vállalkozunk. Melyek azok a föbb tényezők, amellyekkel az állampolgárok politikai intézményekbe vetett bizalmának változását magyarázhatjuk? Cikkünkben megvizsgáljuk, hogy a hazai és nemzetközi szakirodalom alapján az állampolgárok aktív részvétele a közszolgáltatásokban mennyiben lehet az egyik olyan tényező, amely pozitívan befolyásolhatja az önkormányzatokba vetett bizalmat. Bemutatjuk ennek kapcsán a kooperatív közszolgáltatások elméletet, amelyben kiemelt jelentősége van az állam és az állampolgárok közötti kapcsolatnak, ezáltal az állampolgári részvételnek is. A megközelítésünk újszerüsége többrétü, a hazai szakirodalomban kevés a kooperatív közszolgáltatásokkal (coproduction) foglalkozó tanulmány, ezen belül is elszórtak azok a kutatások, amelyek a bizalom szemszögéből vizsgálódnak.

Tanulmányunkban először áttekintjük a hazai és nemzetközi irodalom alapján azokat a tényezőket, amelyek befolyásolhatják a politikai intézményekbe vetett bizalmat, majd kitérünk a kooperatív közszolgáltatások elméletének főbb jelemzőire. Elsősorban a hazai és a nemzetközi szakirodalom elméleti, valamint empirikus kutatásait összegezve válaszoljuk meg a kutatási kérdésünket. Az elméleti összefoglaláson túl, tanulmányunk további célja, hogy a döntéshozók számára olyan hasznosítható tudást adjon, amellyel akár rövid távon is pozitív eredményt érhetnek el az önkormányzatokba vetett bizalmat illetően.

\section{Politikai intézményi bizalom}

A nemzeti politikai intézmények (parlament és kormány) iránti bizalom először az 1970-es években esett vissza, majd azt követően 2007 és 2011 között, a gazdasági válság időszakában csökkent jelentősen az Európai Unió legtöbb tagországában ${ }^{3}$ (MedgyesiBoda 2018: 420). A lehetséges befolyásoló tényezők feltárása érdekében meghatározzuk, hogy mit értünk intézményi bizalom, valamint politikai intézményi bizalom alatt.

A bizalom olyan, jövőre irányuló várakozás, amely szerint a bizalom tárgya (jelen esetben intézmény) az elvárt módon fog cselekedni (Medgyesi-Boda 2018). Tanulmányunkban bizalom alatt ezt a meghatározást alkalmazzuk.

2 Érdekes, hogy Van de Walle, Van Roosbroek és Bouckaert ugyanebben az évben (2008) megjelent cikkükben arra hivják fel a figyelmet, hogy meg kell azt is vizsgálni, hogy miért lett ez a téma fontosabb az elmúlt időszakban, és miért pont éppen ebben az időszakban került a figyelem középpontjába?

3 Az elmúlt időszakban kiemelt figyelmet kapott Görögország esete, amelynek bizalmi válságáról áttekintést ad Ervasti-Kuovo-Venetoklis (2018) tanulmánya. 
Ezt a rövid meghatározást különböző feltételekkel és jellemzőkkel lehet bővíteni. Ezek közül gyakoriak azok a definíciók, amelyekben az államba vetett bizalom azt az állampolgári hitet is jelenti, miszerint az állam korlátozza a saját hatalmát és a közjó érdekében cselekszik (Györffy 2018). További feltételként szokott megjelenni az állammal szemben a demokratikus elvekkel összehangolt müködés, illetve a pártatlanság követelményeinek betartása (Newton 2006; Rothstein 2011). A politikai bizalom szükebben értelmezve az állampolgárok kormányzattal és a választott politikusokkal szembeni várakozását is tükrözi (Denters 2002). K. Blind (2007) szerint a politikai bizalom a közvéleménynek a politikáról alkotott érzéseit írja le. Ha a demokratikus intézményrendszerből indulunk ki, akkor tekinthetjük a politikai legitimáció mutatójának (Rose-Pettersen 2000), valamint tágabban értelmezve, a demokrácia sikeresességét mérő mutatószámnak is (LeeSchachter 2018).

A politikai intézményekbe vetett bizalom esetében elméleti és gyakorlati kérdéseket is felvet a fogalom operacionalizálása. Az 1970-es évek óta a sztenderdizált Eurobarometer kérdőív tartalmaz ugyan kérdést a demokráciával való elégedettségről - aminek eredményeire gyakran hivatkoznak a kormányzatba vetett bizalom egyik mérőszámaként -, ugyanakkor többek szerint ez a mérőszám messze nem írja le tökéletesen a kormányba vetett bizalom mértékét (Van de Walle-Van Roosbroek-Bouckaert 2008). Gyakran felmerülő dilemma, hogy pontosan mit is szeretnénk mérni. Csupán elégedettséget vagy minőségi szempontokat is szeretnénk figyelembe venni? A mérési nehézségeket különbözőképpen kezelve, de a legtöbb tanulmány továbbra is az Eurobarometerhez hasonló módszertant alkalmaz az intézményi bizalom során. Egyre több azon kutatások száma, ahol a társadalmi tőke, az intézményi bizalom és a gazdasági fejlettség, valamint a közpolitikai eredmények kapcsolatával foglalkoznak, és amelyekben a változók közötti pozitív kapcsolatot vélik felfedezni (Knack-Keefer 1997; Garen-Clark 2013). Az állítás, hogy a magasabb bizalmi szint összefüggésben van a gazdagabb régiókkal, a szegényebbek pedig az alacsonyabb bizalmi szinttel, széles körben elfogadott (Leigh 2006). Ennek egyik lehetséges magyarázata, hogy a közpolitikák megvalósíthatósága is nagyban függ a bizalomtól (Boda 2015), de a hosszú távú tervezés és a kiszámíthatóság is inkább a magasabb bizalmi szinttel rendelkező államok sajátja (Győrffy 2012) csakúgy, ahogy a hatékonyság is (Whiteley et al. 2016).

\section{A nemzeti kormány és önkormányzatok közötti különbség}

A szakirodalom többsége az intézményi bizalom eredményváltozójának legtöbbször a nemzeti kormányba, rendőrségbe, bíróságokba, illetve egyéb intézményekbe vetett bizalmat érti. Joggal vetödik fel a kérdés, hogy ebben az esetben mennyire lehet az önkormányzatba és a nemzeti kormányba vetett bizalmat szétválasztani, szükség van-e egyáltalán erre a szétválasztásra, vagy helyesebb lenne inkább egyként kezelni őket. A tanulmányok többsége az utóbbit választja és csak a nemzeti kormányokba vetett bizalmat vizsgálja részletesebben. Emellett szól, hogy sok esetben a magyarázó tényezőknél is makroszintü jelenségekre vezetik vissza a bizalom csökkenésének/növekedésének okát. Erre példa az intézményi bizalom csökkenése a 2007-2008-as gazdasági válság utáni, illetve ezt erősíti, hogy a nemzeti kormányok és az önkormányzatok iránti bizalom változásának dinamikája is legtöbbször hasonló (Wolak-Palus 2010). 
Tanulmányunkban az önkormányzatba és a nemzeti kormányba vetett bizalmat külön kezeljük és főként az önkormányzati bizalomra fókuszálunk, mert véleményünk szerint a bizalmi szint változásának okai részben eltérők a két intézménynél. Az önkormányzatok gyenge teljesítménye inkább a helyi hatóságokba vetett bizalmat csökkenti, míg a nemzeti szintű körülmények a nemzeti kormányba vetett bizalmat befolyásolják (Fitzgerald-Polak 2016), azonban ahogy a legtöbb országban, a helyi szinten megfigyelt bizalom szisztematikusan magasabb, mint a nemzeti szintü (Denters 2002). ${ }^{4}$

Emellett az állampolgároknak eltérőek az elvárásaik a helyi önkormányzattal és a nemzeti kormánnyal szemben (Fitzgerald-Pola 2016; Wolak-Palu 2010). A nemzeti kormányba vetett bizalom esetében sokszor a kormány erejének nagysága és a teljesítménye, míg a helyi önkormányzat esetében leginkább a jobb elszámoltathatóság és a hozzáférhetőség (Jennings 1998) számít. Árnyalja a képet, hogy a helyi és nemzeti kormányzatba vetett bizalom közötti eltérés az önkormányzat méretének növekedésével csökken, vagyis minél nagyobb egy önkormányzat, átlagosan annál kevésbé bíznak benne az állampolgárok (Rose-Pettersen 2000). Ezt a megfigyelést Dánia, Norvégia, Hollandia és az Egyesült Királyság példája is igazolta (Denters 2002).

Milyen tényezők magyarázhatják az eltérést? Fitzgerald és Polak (2016) szerint azok a nemzeti kormányok, amelyek több hatalommal rendelkeznek, átlagosan nagyobb bizalmat kapnak az állampolgároktól, mint azok, amelyekben erőteljesebb a hatalommegosztás a szubnacionális és helyi kormányzatokkal. Hasonló irányú jelenséget figyeltek meg a helyi önkormányzatok esetében is. Azokban az önkormányzatokban, amelyek nagyobb politikai hatalommal rendelkeztek (értelemszerűen a nemzeti kormányok kárára), jobban megbíztak az állampolgárok, míg a nemzeti kormányokban kevésbé. Abban a poltikai döntéshozói szintben (önkormányzat vagy nemezeti kormány) bíznak átlagosan jobban az állampolgárok, ahol úgy érzik, hogy nagyobb ráhatást tudnak gyakorolni. Így ahol a helyi önkormányzat rendelkezik nagyobb hatáskörrel, ott az önkormányzatokba vetett bizalom magasabb (Rose-Lidström 2014).

\section{Magyarázó tényezők}

A következőkben a nemzetközi szakirodalom alapján bemutatunk néhány magyarázó elméletet és tényezőt, amelyek befolyásolhatják a politikai intézményekbe vetett bizalmat. ${ }^{5}$

A szakirodalmi áttekintés alapján négy nagyobb csoportra tudtuk bontani a lehetséges magyarázó tényezőket. Az általunk létrehozott csoportosítás kialakítása során alapvetően Lidström (2008) elkülönítését bővítettük, aki a tényezőknek két nagyobb csoportját különböztette meg, a mikroszintüt és a makroszintüt, valamint Boda (2015) csoportosítását, aki két fó dimenzióra vezeti vissza az intézményi bizalmat: az intézmények észlelt eredeményességére, teljesítményére és hatékonyságára, illetve az intézmények működésével kapcsolatos normatív, etikai elvárásokra.

\footnotetext{
4 A helyi önkormányzatokba vetett bizalom Olaszországban, Spanyolországban, Görögországban a legalacsonyabb (alig több mint 40\%), míg a legmagasabb Franciországban, Belgiumban és Luxemburgban, ahol az állampolgárok több mint 2/3-a bízik (Fitzgerald-Wolak 2016).

5 Tanulmányunkban nem vizsgáljuk az európai intézményekbe vetett bizalmat, amit egy másik kutatásban érdemes lehet külön kiemelni.
} 
A tanulmányunkban használt csoportosítás kialakításánál az önkormányzatokba vetett bizalmat helyeztük előtérbe, illetve azt, hogy az egyes magyarázó tényezőket milyen időtávon képesek az önkormányzatok befolyásolni. Az általunk javasolt magyarázó tényezők a következők: i) gazdasági mutatók, ii) az állampolgárok társadalmi-gazdasági helyzete, iii) helyi közszolgáltatások minősége és iv) az állampolgári részvétel a helyi közszolgáltatások nyújtásában és a közpolitika-alkotás folyamatában. Ezen tényezők alapján egy önkormányzati bizalompiramist alkottunk meg.

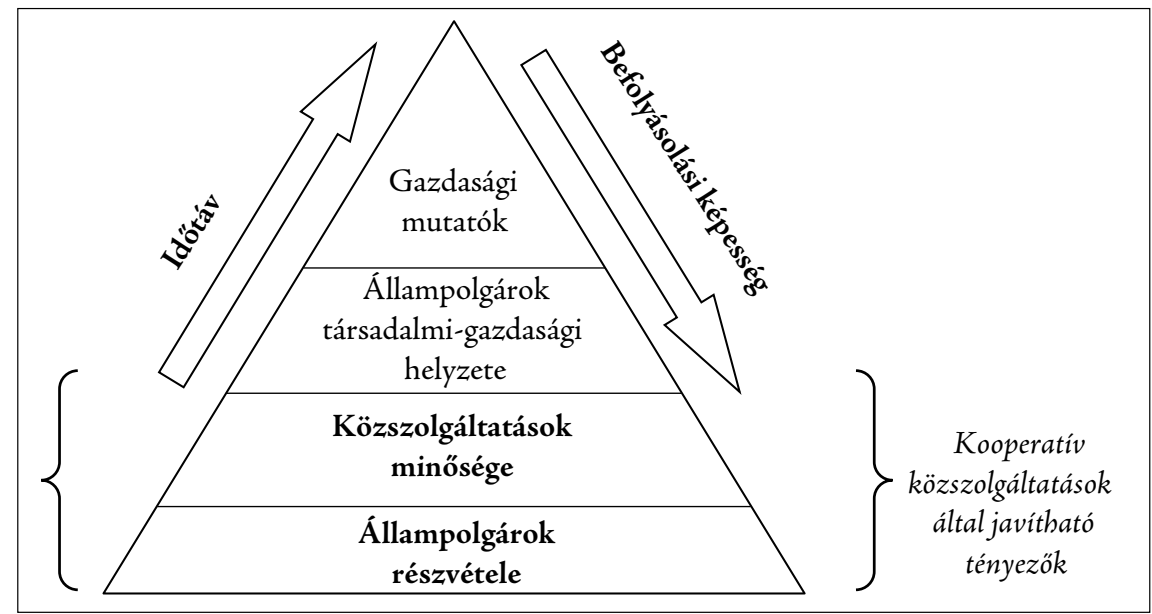

3. ábra: Önkormányzati bizalompiramis (Forrás: saját szerkesztés)

Tanulmányunk későbbi fejezeteiben részletesebben is bemutatjuk az egyes tényezőket, amelyeket az önkormányzatok különböző mértékben tudnak befolyásolni. A tényezők elhelyezkedésést az önkormányzatok befolyásolóképessége és az időtáv befolyásolja. A bizalompiramisban alsó szinten található tényezőre, i) az állampolgárok részvételének intenzitására, az önkormányzat már rövid távon is hatással lehet. ii) A közszolgáltatás tartalmától függően annak minőségére is érdemi hatást tud gyakorolni egy önkormányzat, akár már rövid, de főként középtávon is. iii) A helyi lakosok társadalmi-gazdasági helyzetére viszont már inkább csak közép és hosszú távon, míg iv) a gazdasági mutatókra - ha egyáltalán - csak hosszú távon. Az időtáv tekintetében az általánosan elfogadott intervallumokat használtuk, így rövid távon a 0-3 évet, közép távon a 4-5 évet, míg hosszú távon az 5-10 évet értjük. Az ábrán kiemelve jelöltük azokat a tényezőket, amelyekről úgy gondoljuk, hogy azokat a kooperatív közszolgáltatások elmélet képes közvetlenül befolyásolni.

\section{Gazdasági mutatók}

A kormányzatba vetett bizalom változásának kapcsán az egyik nagyobb magyarázó csoportot a különböző gazdasági mutatók adják. Ezek közé tartoznak az általános gazdasági mutatók, GDP, infláció, foglalkoztatottság, jövedelmek változása (Alesina-Wacziarg 2000; Anderson 2015). Medve-Bálint és Boda (2015: 28) is kiemeli, hogy a gazdaság ál- 
lapotának megítélése erős pozitív kapcsolatban áll az intézmények iránti bizalommal. Amikor alacsony politikai bizalmat látunk, az állampolgárok gondolhatják, hogy a gazdasági rendszer valamelyik eleme rosszul müködik (Lee-Schachter 2018). Az intézményekbe vetett bizalom ugyanis nem csak jövőre vonatkozó várakozásként jelenik meg, sokkal inkább a kormányzat aktuális teljesítményén és az állampolgárok tapasztalatain (Vigoda-Gadot-Mizrabi 2014) múlik.

A gazdasági mutatók esetében kiemelt szerepük van az állapotmutatóknak, ugyanakkor úgy gondoljuk, hogy legalább ennyire, ha nem fontosabb, hogy ezekben a mutatókban milyen változást tapasztalnak az állampolgárok. Hiába alacsony egy országban a foglalkoztatottság szintje, ha például az alacsony bázisnak köszönhetően még ezt az alacsony szintet is nagy emelkedés elözte meg, az emberek úgy fogják érezni, hogy jó eredményt ért el a kormány vagy az önkormányzat.

Ugyanígy fontos, hogy pontosan mi a referenciapont egy társadalmon belül. Sokszor ehhez az általuk választott referenciaponthoz képest ítélik meg az állampolgárok, hogy a kormány vagy önkormányzat mennyire sikeres. Ahogy az elmúlt években Magyarország esetében is láttuk, nem mindegy, hogy Szlovéniához vagy Szlovákiához képest értékeljük a gazdasági mutatóink szintjét és változását vagy Romániáéhoz, Bulgáriáéhoz, illetve Törökországéhoz. Ugyanez természetesen igaz az önkormányzatok esetében is.

Yamamumra (2012) tanulmányában a nagyobb kormányzati méret (bürokrácia) csökkentette a bizalmat, Aghion és munkatársai (Aghion et al. 2010) az országok közötti vizsgálatában találta úgy, hogy az erőteljesebben szabályozó államokban alacsonyabb a bizalom szintje.

Az általános gazdasági mutatókon túl a nagy jövelemi egyenlőtlenségek (Hardin 1999), valamint a politikailag polarizált társadalom is negatív hatással van a kormányzatba vetett bizalomra (Rabn-Rudolph 2005; Zhang-Kim 2018), ahogy a korrupció mértéke is csökkentheti a bizalmat. Híres az 1974-es Miller-Citrin-vita, amely arról szólt, hogy a kormányzat felé mutatott bizalmatlanság csupán a hatalomban levő kormánynyal való elégedetlenség eredménye vagy valójában az egész politikai rezsim elutasítása (Zhang-Kim 2018).

Tanulmányunkban kiemelten a helyi önkormányzatokba vetett bizalommal foglalkozunk, ezért megkülönböztetünk helyi gazdasági mutatókat, amelyeket az önkormányzatok csak hosszú távon tudnak befolyásolni (pl. helyi munkanélküliségi ráta és a helyi átlagos jövedelem). Ezért gondoljuk úgy, hogy a bizalompiramisban a gazdasági mutatók azok, amelyeket a legkevésbé tudnak rövid távon az önkormányzatok befolyásolni. Ez természetesen nem jelenti azt, hogy ezeknek a megváltoztatására nem kell törekedniük az önkormányzatoknak. Üdvözlendő, ha a stratégiaalkotásnál hosszú távú célként szerepelnek ezek a gazdasági mutatók is, mert ezeket a célokat lebontva lehet megfogalmazni azokat az akciókat és programokat, amelyekkel sikeresen javíthatók ezek a mutatók ezáltal is növelve az állampolgárok bizalmi szintjét.

\section{Az állampolgárok társadalmi-gazdasági helyzete}

A kormányzatba vetett bizalom kapcsán több tanulmány az állampolgárok általános jellemzőit, érzékelésüket, illetve magatartásukat vizsgálja (Christensen-Laegreid 2005). A tanulmányok kezdetben főleg ezekre a tényezőkre helyezték a hangsúlyt (MedveBálint-Boda 2015). Az egyéni jövedelem és az iskolázottság szintje rendre szignifikáns- 
nak mutatkozik a vizsgálatok során, és általában a pozitív kapcsolat miatt a magasabb jövedelem és a magasabb iskolázottsági szint nagyobb bizalmat jelent (Rose-Pettersen 2000; Medgyesi-Boda 2018; Newton 2006), bár a nyugat-európai országokkal szemben a kelet-közép-európai országokra vonatkozóan ez az összefüggés nem áll fenn (MedveBálint-Boda 2015).

A z iskolázottsággal összefüggő elmélet mögött sok esetben az a feltételezés áll, hogy az állampolgárok növekvő tudása a nemzeti és helyi kormányzatról szükségképpen nagyobb intézményi bizalomhoz vezet. Ezért hangsúlyosak az átláthatósággal kapcsolatos elméletek is, amelyek azt mondják, hogy a növekvő átláthatóság hozzájárul az állampolgárok növekvő tudásához, így közvetetten a bizalomhoz is (Grimmelikbuijsen 2012; Cuccionelllo-Nasi 2014). A fentebb említettekkel szemben azonban az iskolázottsági szint és a bizalom esetében több tanulmány is negatív kapcsolatot talált (Rose-Pettersen 2000). Ezekben a kutatásokban a tudás és az iskolázottság az állampolgárok növekvő cinizmusát és az egyre erősödő kritikai hozzáállást idézte elő. Amikor az emberek pontosabb képet kapnak a nemzeti parlamentről, mi folyik bent, sok esetben egyre kritikusabbak és negatívabbak lesznek. Egyesek szerint ez a cinizmus egyre nagyobb részben van jelen a társadalmakban (Lidström 2008), ami veszélyeket is rejt magában (Rothstein 2011), ugyanakkor hasznos is lehet (Chanley-Rudolph-Rabn 2000).

$\mathrm{A} z$ iskolázottság kiemelt szerepet kap az állampolgárok egyéni jellemzőit illetően, ugyanakkor az is fontos, hogy állami vagy magánszférában dolgoznak (Lee-Schachter 2018).

Ezek azok a szempontok, amelyeken az önkormányzatok csak közép és hosszú távon képesek változtatni. A településen élő állampolgárok társadalmi és gazdasági helyzetét közép és hosszú távon képes befolyásolni például a helyi oktatási lehetőségek bővítésével, különbözö ösztönző programokkal, új lakók bevonzásával. Magyarország esetében ennek a vizsgálatnak külön jelentőséget ad, hogy az elmúlt évek átalakítását követően az iskolák fenntartása már nem az önkormányzatok feladata, így kérdés, hogy ezáltal mennyiben tudnak az önkormányzatok a helyi oktatási lehetőségeken javítani. Ebből adódóan új típusú megoldásokat kell keresniük az önkormányzatoknak ahhoz, hogy ezeken a tényezőkön érdemben változtatni tudjanak.

\section{A közszolgáltatások minősége}

A közszolgáltatások minőségével és az intézményi bizalom pozitív kapcsolatával számos tanulmány foglalkozik (Lidström 2008). Rose és Pettersen (2000) Norvégiában végzett kutatásukban állapították meg, hogy erős kapcsolatot találtak az állampolgárok közszolgáltatásokkal való elégedettsége és a politikai intézményekbe vetett bizalma között. Hasonló eredményre jutott Medgyesi-Boda (2018: 415), akik többek között az European Quality of Life Surveys (EQLS) adataira alapozva úgy találták, hogy a közszolgáltatások minőségével való általános elégedettség az egyik legerősebb változó, ami előre jelezte a politikai intézményekbe vetett bizalmat. Christensen és Laegreid (2005) is hasonló eredményre jutottak, felmérésükben a közszolgáltatásokkal leginkább elégedettek bíztak legjobban a kormányzatban.

A közszolgáltatások minőségével való összefüggés megjelenése az intézményi bizalom kapcsán új szempontokat jelenthet a nemzeti kormányok és az önkormányzatok esetében is. Ha az önkormányzatok részletesen megvizsgálják a közszolgáltatásaikat, 
akkor azok javításával akár már rövid távon is eredményeket érhetnek el. A másik szempont, hogy az önkormányzatoknak törekedniük kell arra, hogy meghatározó szereplők legyenek a közszolgáltatások kapcsán, ugyanis ahogy korábban is láttuk, a nagyobb befolyás is jelenthet nagyobb bizalmat, illetve az ezzel járó lehetőség, hogy érdemben változtatni tudnak a helyi viszonyokon. Elméleti szempontból is új lehetőségeket vet fel ez a megfigyelés, hiszen ráírányítja a figyelmet, hogy próbáljuk meg megérteni, mik is azok a közszolgáltatások pontosan, és ezekben mit jelent pontosan a minőség?

Ezért is gondoljuk úgy, hogy fontos eredményeket hozhat, ha részletesebben vizsgáljuk a kooperatív közszolgáltatások elméletetét, ugyanis az lehetőséget biztosít a helyi önkormányzatoknak, hogy akár már rövid távon is jelentős eredményeket érjenek el a közszolgáltatások minőségét illetően, és így növeljék a beléjük vetett bizalmat.

\section{Állampolgári részvétel}

Bizalompiramisunk első szintjét az állampolgári részvétel, annak intenzitása és minősége adja. A nemezetközi irodalommal egyetértve úgy gondoljuk, hogy az állampolgári részvétel erősítése nagyban hozzájárulhat az önkormányzatba vetett bizalom növekedéséhez. Azokban az országokban, ahol az állampolgárok erőteljesebben be vannak vonva a helyi és nemzeti döntéshozatalba, jobban megbíznak az önkormányzatokban, illetve a kormányokban (Christensen-Laegreid 2005).

Az állampolgári részvétel olyan tevékenység, amelyen keresztül az állampolgár kísérletet tehet a kormányzat befolyásolására, hogy az a számára preferált módon cselekedjen (Lee-Schachter 2018). Az állampolgári részvétellel kapcsolatos elméletek már a korai gondolkodóknál is megjelentek. Így de Tocqueville-nál, aki Millhez hasonlóan úgy vélte, a helyi közösségekben és az önkéntes szervezetekben való részvétel szolidaritásra, kooperációra és kölcsönösségre tanít, valamint növeli a bizalmat a résztvevőkben, ami nélkülözhetetlen a demokrácia müködéséhez (Newton 2006).

$\mathrm{A} z$ állampolgárok bevonásával és részvételével kapcsolatos elképzelések már több állam kormányának stratégiájában megjelent, amitől egyrészt a kormányzati hatékonyság javulását (Cuccionelllo-Nasi 2014), másrészt a kormányzatba vetett bizalom növekedését várják (Kim-Lee 2012). Ezenfelül érdekes visszacsatolási mechanizmus figyelhető meg az állampolgári részvétel kapcsán. Egyrészt az intézményi bizalom tekinthető output változónak is, azonban tekinthetjük input változóként is. Nincs minden kutató között egyetértés abban, hogy a növekvő állampolgári részvételi hajlandóságot az alacsony intézményi bizalom idézi elő, vagyis a bizalom hiánya, ami ösztönzi az állampolgárokat arra, hogy beleszóljanak a politikai döntéshozatalba (pl. korrupt állam esetében), vagy éppen fordítva: egy nagyobb bizalmi szint az, ami arra motiválja az embereket, hogy aktív állampolgárként igyekezzenek részt venni a döntéshozatalban. Utóbbi esetében a bizalom hiánya az állampolgári apátiát vonja maga után (Lee-Schachter 2018).

Úgy gondoljuk, hogy az állampolgári részvétel erősítése az egyik tényező, amely növelheti az önkormányzatokba vetett bizalmat, ugyanakkor a bizalom sajátossága miatt ehhez már egy adott bizalmi szintre van szükség. Ahhoz, hogy az állampolgárok részt vegyenek a folyamatokban és így aktív állampolgárok legyenek, valamilyen minimális bizalomnak kell lennie a szereplők között, máskülönben az apátia lesz a jellemző a szereplőkre, de ha ez a minimális szint megvan, akkor a résztvétel hozzájárulhat ennek a szintnek az erősítéséhez. Piramisunkban ezt a tényezőt helyeztük a legalsó szintre, 
mert úgy véljük, hogy ezen az önkormányzatok nagyban tudnak javítani, és különféle eszközökkel mindezt már rövid távon is meg tudják tenni.

\section{Kooperatív közszolgáltatások}

A fentebb ismertetett tényezők, valamint az önkormányzati bizalompiramis megmutatta azokat a magyarázó tényezőket, amelyek szerintünk befolyásolhatják az állampolgárok poltikai intézményekbe vetett bizalmát. Úgy gondoljuk, hogy a piramis két szintjének (állampolgári részvétel, közszolgáltatások minősége) javítására és erősítésére a kooperatív közszolgáltatások elmélet szemléletével és eszközeivel van lehetőség. Ebben a fejezetben először röviden bemutatjuk a kooperatív közszolgáltatások (co-production) irányzat elméleti megfontolásait és előzményeit.

Azt láthatjuk az utóbbi időben, hogy a bürokrácia és a közpolitika újragondolásáról, megújításáról való vitáknak vagyunk a szemtanúi (Vigoda-Gadot-Mizrabi 2014). A közpolitika és a közigazgatási reformokat az 1970-es évektől domináló Új Közszolgálati Menedzsment (NPM) több helyen kudarcot vallott (Osborne 2018), ami így új irányzatok megjelenését hozta magával, amelyek nagyrészt az NPM-ből építkezve, de azzal szemben fogalmazzák meg magukat. Habár a kooperatív közszolgáltatások irányzatot megalapozó tanulmányok már az 1980-as évekbenben megjelentek (Parks et al. 1981), közpolitikai és kutatási szinten napjainkban tett szert újra egyre növekvő népszerüségre (Brandsen-Honigh 2016; Filipe-Renedo-Marston 2017).

$\mathrm{A} z$ általunk használt rövid definíció szerint kooperatív közszolgáltatásokról (coproduction) akkor beszélhetünk, ha a közszolgáltatások minősége és eredménye részben a bevont és aktív állampolgárokon vagy azok szervezetén (civil szervezetek) múlik (Loeffler et al. 2008). A definícióban megjelenő állampolgári bevonás egy átalakuló közszolgáltatásnyújtást hoz magával. A klasszikus, tradícionális megközelítésben egyedül az állam és szervezetei nyújtják az állampolgárok felé a közszolgáltatásokat (bürokratikus koordináció). Az NPM típusú megközelítésben ezt a feladatot részben vagy teljesen a piaci koordináció látja el. Ebben a dichotómiában a kooperatív közszolgáltatások egy harmadik utat képvisel, ahol a közszolgáltatásokat nemcsak az állam és nemcsak a piac, hanem az állam az állampolgárokkal és a közösségel közösen állítja elő (DavisOstrom 1991; Brandsen-Honigh 2016; Pestoff 2009).

Sok esetben a közszolgáltatás előállítása és a fogyasztása elválaszthatatlanná vált (Loeffler et al. 2008), ezért a továbbiakban már nem elegendő, ha az igénybevevő állampolgárok csak a folyamat végén „kapcsolódnak be”. Az állam és az állampolgárok között létrejövő együttműködés alapjaiban változtatja meg az eddigi gyakorlatot, mert csökken a közöttük lévő távolság, illetve a határok is egyre inkább elmosódnak (FilipeRenedo-Marston 2017). Az állampolgárokra már nem passzív szereplőként vagy egyszerü vásárlóként kell tekintenie az államnak, hanem potenciális együttműködőre (Fledderus-Brandsen-Honingh 2014). Ebben az esetben az állampolgárok kevésbé függnek az államtól és egyben nagyobb felelősséget, beleszólást kapnak a közszolgáltatásokba (Loeffler et al. 2008). Ezt a folyamatot nagyban segíti az napjainkban is zajló informatikai fejlődés, aminek köszönhetően minden eddiginél könnyebben és kisebb költséggel valósulhat meg a szereplők együttműködése, valamint a szolgáltatásnyújtás. Ezáltal az állami tisztviselők is új kihívásokkal néznek szembe, hiszen eddig az állampolgárok nélkül látták el a feladataikat. Részben jogosan érezhetik, hogy ebben az új megközelítés- 
ben vesztesként tünnek fel, mert az állampolgárok valamit „elvesznek” tőlük (BrandsenHoningh 2016). Azonban több empirikus (főként nyugat-európai) vizsgálat azt mutatja, hogy ma már az állami szereplők is felismerik, hogy szükségük van az állampolgárokra a minőségi és hatékony közszolgáltatáshoz (Loeffler et al. 2008).

A z állami tisztviselőkön túl az állampolgárok is új kihívásokkal szembesülnek, szerepük növekedésével együtt nő a felelősségük is, ami így egyben elszámoltathatóvá is teszi őket. Ezt a terhet azonban sok állampolgár nem kívánja felvállalni ${ }^{6}$ (Fledderus-BrandsenHoningh 2014). Az okok jobb megértése miatt az állampolgárok motivációjának vizsgálata jelenleg is a kutatások középpontjában áll - például Loeffler és munkatársai reprezentatív felmérésen keresztül vizsgálták öt európai országban a kooperatív köszolgáltatások kapcsán az állampolgárok motivációit és egyéni jellemzőit (Loeffler et al. 2008).

A kooperatív közszolgáltatások elmélet a közszolgáltatásnyújtás hatékonyságának javításával megpróbál választ adni a növekvő állami költségekre, az állampolgárok elvárásainak megfelelően tervezett szolgáltatosokkal a minőség romlására, míg a részvételi folyamaton keresztül az általános és intézményi bizalom csökkenésére.

\section{Körmechanizmus}

A koopertív közszolgáltatások során az állampolgárok egyénenként vagy közösségben (pl. civil szervezeten keresztül) vesznek részt a közszolgáltatás nyújtásában. ${ }^{7} \mathrm{Az}$ aktív civil közösség hozzájárulhat a gazdasági fejlettséghez (Putnam-Leonardi-Nanetti 1993), valamint a társadalmi tőke növeléséhez is (Pestoff 2009; Rothstein 2011). Az állampolgárok aktivitása elengedhetetlen, de ennek kezdeti bizalmi feltételei is vannak. $\mathrm{A} z$ állampolgárok sokszor csak abban az esetben hajlandók részt venni a folyamatban, ha azt látják, hogy hasznuk több, mint a befektetett energiájuk.

Ehhez az is szükséges, hogy az állam/önkormányzat hiteles szereplőként jelenjen meg, akinek az igérete hihető, valamint biztosítja a tényleges beleszólást a szolgáltatás előállításába (Fledderus 2015). A svájci iskolákban a szülők bevonása akkor volt sikeres, amikor valódi beleszólást kaptak az iskola müködésébe (Gundelach-Buser-Kübler 2017), Pál (2015) tanulmánya hasonló jelenséget figyelt meg egy budapesti városrehabilitációs program során, ahol a lakosok kezdetben a bizalmatlanságukat jelezték, valamint kételkedtek abban, hogy ténylegesen beleszólhatnak majd a program tartalmi elemeibe. A helyi önkormányzatok esetében kiemelt szerepük van az önkormányzat vezetőinek, így a polgármesternek is, ${ }^{8}$ aki aktivitásával, elhatározásával nagyban hozzájárulhat a folyamat sikeréhez.

A különbözö közszolgáltatásokban (lakhatás, környezetvédelem, közlekedés, közbiztonság stb.) való részvétel megvalósításában nagy szerepet kapnak a különböző e-kormányzattal kapcsolatos intézkedések, amelyek a rendszeres interakció megvalósításával elősegíthetik az állampolgár bevonását, és ezáltal a helyi önkormányztatba vetett bizalmat (Tolbert-Mossberger 2006; Cuccionelllo-Nasi 2014).

\footnotetext{
Az állampolgár lehetséges szerepeit Loeffler (Loeffler et al. 2008) egy „nullától a hősig” (hero to zero) terjedő skálával szemlélteti.

Három szakaszt szokás megkülönböztetni: a tervezést, a végrehajtást és az ellenőrzést.

A polgármester és a bizalom kapcsolatával foglalkozik Noda (2017).
} 
A kooperatív közszolgáltatások elmélete közvetlenül két fontos csatornán keresztül is képes az államba és az önkormányzatba vetett bizalom növelésére: az i) állampolgári részvétel erősítésével és ii) a közszolgáltatások minőségének javításával. Az állampolgári bevonás szükségességének egyik oka, hogy az állam a közszolgáltatásokat ma már csak az állampolgárokkal együtt, közösen tudja elóállítani, mert a komplex folyamatok miatt a szolgáltatásokhoz nem áll az önkormányzat és az állam rendelkezésére elegendő tudás (Boyle-Harris 2009). Az együttmüködés eredményeképpen az állampolgárok beleszólhatnak a közszolgáltatásokba, ami - ahogy láttuk korábban - hozzájárulhat a bizalom növekedéséhez. A másik közvetlen csatorna a közszolgáltatás minőségének javítása, ami a korábbi felmérések alapján a legfontosabb mérőszáma volt az intézményi bizalomnak. Azáltal, hogy az igénybevevőkre szabott és az ő igényeiknek megfelelő közszolgáltatások valósulnak meg, javul a hatékonyság és a minőség is, ami így hozzájárul a bizalom növekedéséhez.

Azért gondoljuk úgy, hogy a kooperatív közszolgáltatások elméletének gyakorlati alkalmazására van szükség, mert ez az elmélet és ennek eszköztára az, amely az önkormányzatokba vetett bizalom négy tényezője közül éppen az első kettőt, az állampolgárok részvételét és a közszolgáltatások minőségét helyezi előtérbe és ezekre ad megoldást (lásd 2. ábra). Valamint ez a két tényező az, amelyet az önkormányzatok már rövid távon is képesek javítani.

$\mathrm{A} z$ aktív, közvetlen állampolgári részvétel által közvetetten javulhat az önkormányzat és az állami feladatok átláthatósága is, ami szintén növelheti az intézményi bizalmat - természetesen csak abban az esetben, ha minden megfelelően müködik. Ez egyben kockázatot is jelenthet az olyan önkormányzatok és kormányzatok számára, amelyek korruptak, hiszen az állampolgári ellenőrzésen keresztül nő a lebukás veszélye.

\section{Befejezés}

Tanulmányunkban arra kerestük a választ, hogy milyen tényezök járulhatnak hozzá a politikai intézményekbe vetett bizalom növekedéséhez? Propozíciónk szerint a kooperatív közszolgáltatások és ezen keresztül az állampolgári részvétel hozzájárulhat a helyi önkormányzatokba vetett bizalom növeléséhez.

Először áttekintettünk néhány főbb, a politikai intézményi bizalomat befolyásoló magyarázó tényezőt. Ezek alapján négy csoportot különítettünk elः i) a gazdasági mutatókat, ii) az állampolgárok társadalmi-gazdasági helyzetét, iii) a közszolgáltatások minőségét és iv) az állampolgárok részvételét.

A tényezőket önkormányzati bizalompiramisba szerveztük. A tényezők piramison belüli elhelyezkedését az határozta meg, hogy az önkormányzatok milyen időtávon tudják ezeket megváltoztatni és milyen befolyásolóképességgel bírnak ezekre a tényezőkre. Hosszú távon az önkormányzat a helyi gazdasági mutatókat, illetve az állampolgárok társadalmi-gazdasági helyzetét, míg rövid és középtávon a közszolgáltatások minőségét, rövid távon az állampolgárok részvételi intenzitását tudja befolyásolni.

Cikkünk második részében röviden ismertettük a kooperatív közszolgáltatások elméletetét, valamint kitértünk a lehetséges bizalmat növelő csatornákra. Ezek alapján rávilágítottunk arra, hogy az önkormányzatok az elmélet alapján éppen a bizalompiramis két alsó szintjére lehetnek hatással. Ez a két tényező az állampolgári részvétel erőssége és a közszolgáltatások minősége, amelyeken akár már rövid távon is tudnak javítani 
az önkormányzatok. Ezért gondoljuk úgy, hogy az elméletnek gyakorlati, policy alkotási jelentősége is van és ezáltal gyakorlati szakemberek számára is releváns.

A közszolgáltatások eltérőek lehetnek abból a szempontból is, hogy melyik kormányzati szintnek van meg a megfelelő felelősségi és hatásköre ahhoz, hogy javítani tudjon a hatékonyságon és a minőségen. Az elmélet gyakorlati alkamazhatósága nem feltétlen szorítkozik az önkormányzati szintre, ugyanez értelmezhető nemzeti szinten, illetve szervezeti szinten is. Az oktatásra gondolva szervezeti szinten megvalósulhat együttmüködés akár az iskolai szervezetek/vezetők és a szülők esetében, ahogy Galli és munkatársai azt bemutatták az olasz iskolai étkeztetés példáján vagy amikor az oktatásirányítás az állampolgárok vagy szervezeteikkel együtt dönt a fejlesztések irányáról és azok megvalósításáról (Galli et al. 2014).

Kutatásunk megerősítette azt a propozíciónkat, hogy a kooperatív közszolgáltatásokon keresztül az állampolgári részvétel növelése hozzájárulhat az intézményi bizalom növekedéséhez.

További kutatásra van azonban szükség, hogy empirikus hazai és nemzetközi eredményekkel is megpróbáljuk alátámasztani az általunk ismertetett mechanizmust, illetve hogy esettanulmányokon keresztül részletesebben mutassuk be az elmélet gyakorlati hasznait.

\section{IRODALOM}

Aghion, Ph., Algan, Y., Cahuc, P. \& Shleifer, A. (2010) "Regulation and Distrust." Quarterly Journal of Economics, Vol. 125. No. 3. pp. 1015-1049.

Alesina, A. \& Wacziarg, R. (2000) The Economics of Social Trust. In: S. Pharr \& R. Putnam (eds) Disaffected Democracies. Princeton (NJ), Princeton University Press.

Anderson, J. E. (2015) The Economic Crisis and Its Impact on Trust in Institutions in Transition Countries. SSRN Electronic Journal, https://doi.org/10.2139/ssrn.2652265

Boda Zs. (2015) Intézményi bizalom és a közpolitikák eredményessége. In: Boda Z. (ed.) Bizalom és közpolitika - Jobban müködnek-e az intézmények, ba biznak bennük? Budapest, Argumentum-MTA TK Politikatudományi Intézet.

Boyle, D. \& Harris, M. (2009) The Challenge of Co-production. https://media.nesta.org. uk/documents/the_challenge_of_co-production.pdf [Letöltve: 2016. 10. 20.]

Brandsen, T. \& Honingh, M. (2016) Distinguishing Different Types of Coproduction: A Conceptual Analysis Based on the Classical Definitions. Public Administration Review, Vol. 76. No. 3. pp. 427-435. https://doi.org/10.1111/puar.12465

Chanley, V. A., Rudolph, T. J. \& Rahn, W. M. (2000) The Origins and Consequences of Public Trust in Government. Public Opinion Quarterly, Vol. 64. No. 3. pp. 239-256. https://doi.org/10.1086/317987

Christensen, T. \& Laegreid, P. (2005) Trust in Government: The Relative Importance of Service Satisfaction, Political Factors, and Demography. Public Performance E Management Review, Vol. 28. No. 4. pp. 487-511. https://doi.org/10.1080/15309576.2005.1105 1848

Cucciniello, M. \& Nasi, G. (2014) Transparency for Trust in Government: How Effective Is Formal Transparency? International Journal of Public Administration, Vol. 37. No. 13. pp. 911-921. https://doi.org/10.1080/01900692.2014.949754 
Davis, G. \& Ostrom, E. (1991) A Public Economy Approach to Education: Choice and Co-Production. International Political Science Review, Vol. 12. No. 4. pp. 313-335. https://doi.org/10.1177/019251219101200405

Denters, B. (2002) Size and Political Trust: Evidence from Denmark, the Netherlands, Norway, and the United Kingdom. Environment and Planning C: Government and Policy, Vol. 20. No. 6. pp. 793-812. https://doi.org/10.1068/c0225

Ervasti, H., Kouvo, A. \& Venetoklis, T. (2018) Social and Institutional Trust in Times of Crisis: Greece, 2002-2011. Social Indicators Research. https://doi.org/10.1007/s11205018-1862-y

Eurobarometer (2017) Designing Europe's future: Trust in institutions, Globalisation, Support for the Euro, Opinions about Free Trade and Solidarity. Special Eurobarometer 461, Wave EB87.2, Elérhető forrás: http://ec.europa.eu/commfrontoffice/publicopinion/ index.cfm/ResultDoc/download/DocumentKy/78778 [Letöltve: 2018. 11. 14.]

Filipe, A., Renedo, A. \& Marston, C. (2017) The Co-production of What? Knowledge, Values, and Social Relations in Health Care. PLOS Biology, Vol. 15. No. 5. pp. e2001403. https://doi.org/10.1371/journal.pbio.2001403

Fitzgerald, J. \& Wolak, J. (2016) The Roots of Trust in Local Government in Western Europe. International Political Science Review, Vol. 37. No. 1. pp. 130-146. https://doi. org/10.1177/0192512114545119

Fledderus, J. (2015) BuildingTtrust through Public Service Co-production. International Journal of Public Sector Management, Vol. 28. No. 7. pp. 550-565. https://doi. org/10.1108/IJPSM-06-2015-0118

Fledderus, J., Brandsen, T. \& Honingh, M. (2014) Restoring Trust Through the CoProduction of Public Services: A Theoretical Elaboration. Public Management Review, Vol. 16. No. 3. pp. 424-443. https://doi.org/10.1080/14719037.2013.848920

Galli, Fr., Brunori, G., Di Iacovo, F. \& Innocenti, S. (2014) Co-Producing Sustainability: Involving Parents and Civil Society in the Governance of School Meal Services. A Case Study from Pisa, Italy. Sustainability, Vol. 6. No. 4. pp. 1643-1666.

Garen, J. E. \& Clark, J. R. (2013) Trust and the Growth of Government. SSRN Electronic Journal. https://doi.org/10.2139/ssrn.2366081

Grimmelikhuijsen, S. (2012) Linking Transparency, Knowledge and Citizen Trust in Government: an Experiment. International Review of Administrative Sciences, Vol. 78. No. 1. pp. 50-73. https://doi.org/10.1177/0020852311429667

Gundelach, B., Buser, P. \& Kübler, D. (2017) Deliberative Ddemocracy in Local Governance: The Impact of Institutional Design on Legitimacy. Local Government Studies, Vol. 43. No. 2. pp. 218-244. https://doi.org/10.1080/03003930.2016.1261699

GyőrfFy D. (2012) Intézményi bizalom és a döntések időhorizontja. Közgazdasági Szemle, No. 4. pp. 412-425.

Győrffy D. (2018) Trust and Crisis Management in the European Union: An Institutionalist Account of Success and Failure in Program Countries (1st edition 2018). Cham (Switzerland), Palgrave Macmillan.

Hardin, R. (1999) Do We Want Trust in Government? In: M. E. Warren (ed.) Democracy and Trust (pp. 22-41). Cambridge, Cambridge University Press. https://doi. org/10.1017/CBO9780511659959.002

Jennings, M. (1998) Political Trust and the Roots of Devolution. In: K. Cook \& R. Hardin (Authors) \& V. Braithwaite \& M. Levi (eds) Trust and Governance. Russell Sage Foundation. pp. 218-244 
Jennings W., Clarke, N., Stoker, G. \& Moss, J. (2015) Popular Understandings of Politics in Britain, 1937-2014. U.K.Political Studies Association annual conference, Sheffield.

K. Blind, P. (2007) Building Trust in Government in the Twenty-First Century: Review of Literature and Emerging Issues. 7th Global Forum on Reinventing Government Building Trust in Government, Vienna.

Kıм, B. S. \& Kıм, J. H. (é. n.) Increasing Trust in Government through More Participatory and Transparent Government.

Kim, S. \& LeE, J. (2012) E-Participation, Transparency, and Trust in Local Government. Public Administration Review, Vol. 72. No. 6. pp. 819-828. https://doi.org/10.1111/ j.1540-6210.2012.02593.x

Knack, S. \& Keefer, P. (1997). Does Social Capital Have an Economic Payoff? A CrossCountry Investigation. The Quarterly Journal of Economics, Vol. 112. No. 4. pp. 12511288.

Kontler, L. \& Somos, M. (eds, 2017) Trust and Happiness in the History of European Political Thought. Brill. https://doi.org/10.1163/9789004353671

Lee, Y. \& Schachter, H. L. (2018) Exploring the Relationship between Trust in Government and Citizen Participation. International Journal of Public Administration, 1-12. https://doi.org/10.1080/01900692.2018.1465956

Leigh, A. (2006) Trust, Inequality and Ethnic Heterogeneity. Economic Record, Vol. 82. No. 258. pp. 268-280, https://doi.org/10.1111/j.1475-4932.2006.00339.x.

Lidström, A. (2008) Political Trust and the Local Business Climate: Evidence from Sweden. Scandinavian Political Studies, Vol. 31. No. 4. pp. 384-407. https://doi. org/10.1111/j.1467-9477.2008.00214.x

Loeffler, E., Parrado, S., Bovaird, T. \& Van Ryzin, G. (2008) 'If You Want to Go Fast, Walk Alone. If You Want to Go Far, Walk Together': Citizens and the Co-production of Public Services. Paris, French Ministry of Budget, Public Finances and Public Services, on behalf of the Presidency of the EU.

Medgyesi M. \& Boda Z. (2018) Intézményekbe vetett bizalom Magyarországon és az Európai Unió országaiban. Társadalmi Riport, Vol. 15. No. 1. pp. 414-433.

Medve-BÁlint G. \& Boda Z. (2015) Az egyenlőtlenség és a jövedelem hatása az intézményi bizalomra. In: Boda Z. (ed.) Bizalom és közpolitika - Jobban müködnek-e az intézmények, ha biznak bennük? Budapest, Argumentum-MTA TK Politikatudományi Intézet.

Newton, K. (2006) Institutional Confidence and Social Trust: Aggregate and Individual Relations. In M. Torcal \& J. R. Monterp, Political Disaffection in Contemporary Democracies Social Capital, Institutions and Politics. Routledge.

Noda, Y. (2017) Trust in the Leadership of Governors and Participatory Governance in Tokyo Metropolitan Government. Local Government Studies, Vol. 43. No. 5. pp. 776797. https://doi.org/10.1080/03003930.2017.1333428

Osborne, S. P. (2018) From Public Service-Dominant Logic to Public Service Logic: Are Public Service Organizations Capable of Co-production and Value Co-creation? Public Management Review, Vol. 20. No. 2. pp. 225-231. https://doi.org/10.1080/14719037. 2017.1350461

PÁL G. (2015). Mi legyen a falakkal? A Magdolna-negyed esete. In: Boda Z. (ed.) Bizalom és közpolitika - Jobban müködnek-e az intézmények, ha biznak bennük? Budapest, Argumentum-MTA TK Politikatudományi Intézet.

Parks, R. B., Baker, P. C., Kiser, L., Oakerson, R., Ostrom, E., Ostrom, V., ... \& Wilson, R. (1981) Consumers as Coproducers of Public Services: Some Economic and 
Institutional Considerations. Policy Studies Journal, Vol. 9. No. 7. pp. 1001-1011. https:// doi.org/10.1111/j.1541-0072.1981.tb01208.x

Pestoff, V. A. (2009) A Democratic Architecture for the Welfare State. London; New York, Routledge.

Pew Research Center (2019) Public Trust in Government: 1958-2019. https://www.peoplepress.org/2019/04/11/public-trust-in-government-1958-2019 [Letöltve: 2019. 04. 12.]

Putnam, R. D., Leonardi, R. \& Nanetti, R. (1993) Making Democracy Work: Civic Traditions in Modern Italy. Princeton (NJ), Princeton University Press.

Rahn, W. M. \& Rudolph, T. J. (2005) A Tale of Political Trust in American Cities. Public Opinion Quarterly, Vol. 69. No. 4. pp. 530-560. https://doi.org/10.1093/poq/nfi056

Roos, K. \& Lidström, A. (2014) Local Policies and Local Government Legitimacy. The Swedish Case. Urban Research E Practice, Vol. 7. No. 2. pp. 137-152. https://doi.org/10. 1080/17535069.2014.910920

Rose, L. E. \& Pettersen, P. A. (2000) 2. The Legitimacy of Local Government - What Makes a Difference? Evidence from Norway. In: Research in Urban Policy (Vol. 8. pp. 25-65). Bingley: Emerald (MCB UP). https://doi.org/10.1016/S1479-3520(00)80006-9

Rothstein, B. (2011) The Quality of Government: Corruption, Social Trust, and Inequality in International Perspective. Chicago; London, University of Chicago Press.

Tolbert, C. J. \& Mossberger, K. (2006) The Effects of E-Government on Trust and Confidence in Government. Public Administration Review, Vol. 66. No. 3. pp. 354-369. https://doi.org/10.1111/j.1540-6210.2006.00594.x

Van de Walle, S., Van Roosbroek, S. \& Bouckaert, G. (2008) Trust in the Public Sector: Is There Any Evidence for a Long-Term Decline? International Review of Administrative Sciences, Vol. 74. No. 1. pp. 47-64. https://doi.org/10.1177/0020852307085733

Vigoda-Gadot, E. \& Mizrahi, S. (2014) Managing Democracies in Turbulent Times: Trust, Performance, and Governance in Modern States. Heidelberg (Germany), Springer.

Whiteley, P., Clarke, H. D., Sanders, D. \& Stewart, M. (2016) Why Do Voters Lose Trust in Governments? Public Perceptions of Government Honesty and Trustworthiness in Britain 2000-2013. The British Journal of Politics and International Relations, Vol. 18. No. 1. pp. 234-254. https://doi.org/10.1111/1467-856X.12073

Wolak, J. \& Palus, C. K. (2010) The Dynamics of Public Confidence in U.S. State and Local Government. State Politics E Policy Quarterly, Vol. 10. No. 4. pp. 421-445. https:// doi.org/10.1177/153244001001000407

Yamamura, E. (2012) “Government Size and Trust.” Review of Social Economy, Vol. 70. No. 1. pp. 31-56.

Zhang, Y. \& Kiм, M.-H. (2018) Do Public Corruption Convictions Influence Citizens' Trust in Government? The Answer Might Not Be a Simple Yes or No. The American Review of Public Administration, Vol. 48. No. 7. pp. 685-698. https://doi. org/10.1177/0275074017728792

A cikk a Creative Commons Attribution 4.0 International License (https://creativecommons.org/licenses/ by/4.0/) feltételei szerint publikált Open Access közlemény, melynek szellemében a cikk bármilyen médiumban szabadon felhasználható, megosztható és újraközölhető, feltéve, hogy az eredeti szerző és a közlés helye, illetve a CC License linkje és az esetlegesen végrehajtott módosítások feltüntetésre kerülnek. (SID_1) 